УДК 347.98

DOI https:/ / doi.org/10.32837/yuv.v0i1.2093

\author{
М. Майка, \\ адвокат, \\ кандидат юридичних наук, \\ викладач кафедри права юридичного факультету \\ Галицького коледжу імені В'ячеслава Чорновола
}

\title{
ПРОБЛЕМИ ПРАВОЗАСТОСУВАННЯ \\ ЦИВІЛЬНО-ПРОЦЕСУАЛЬНИХ ОЦІНОЧНИХ ПОНЯТЬ НА СТАДІЇ КАСАЦІЙНОГО ПЕРЕГЛЯДУ СУДОВИХ РІШЕНЬ
}

Постановка проблеми. Аксіологічний підхід до тлумачення формальної визначеності правової норми, як ознаки права, зумовлює необхідність застосування у процесі законотворчості оціночних правових понять, тому об’єктивна неспроможність законодавця регламентувати широку сферу правовідносин усувається внаслідок застосування термінів невизначеного змісту. Не $є$ виключенням і положення чинного Цивільного процесуального кодексу України, що визначають процедуру касаційного перегляду судових рішень у цивільних справах, де законодавець застосував оціночні правові поняття для визначення критеріїв прийнятності касаційної скарги. Повноваження юрисдикційного органу щодо розширювального тлумачення обсягу цивільно-процесуальних оціночних понять та відсутність конкретизаціі ї нормативного змісту, створює як позитивні, так i негативні наслідки під час здійснення правозастосування на стадіï касаційного перегляду судових рішень у цивільному процесі. У зв'язку 3 наведеними обставинами, а також притаманною ознакою остаточності рішень суду касаційної інстанції по суті справи, проблеми застосування оціночних понять під час касаційного провадження не втрачають актуальності у сучасних правових реаліях, a їх дослідження, ретельний аналіз та визначення пропозицій щодо законодавчих змін створює передумови для формування належної правозастосовчої практики.

Стан дослідження. Проблемні питання касаційного перегляду судових рішень у цивільних справах відображені у роботах таких науковців, як: Д. Луспеник, Й. Богдан, С. Фурса, А. Монаєнко, Р. Ханова та інших. Проблеми застосування оціночних понять у процесуальному праві досліджували: І.В. Турчин-Кукаріна, І.П. Зеленко, В.Г. Перепелюк. Водночас, станом на даний час, відсутні наукові роботи, які б здійснювали аналіз проблем правозастосування цивільно-процесуальних оціночних понять на стадіï перегляду судових рішень у касаційному порядку за правилами та у редакції ЦПК України визначеній Законом України № 460-IX «Про внесення змін до Господарського процесуального кодексу України, Цивільного процесуального кодексу України, Кодексу адміністративного судочинства України щодо вдосконалення порядку розгляду судових справ» від 15.01.20 [17].

Мета дослідження. На основі викладеного формуємо мету дослідження: здійснення теоретико-правової характеристики цивільно-процесуальних оціночних понять на стадії касаційної перегляду судових рішень, визначення проблем законодавства 
та правозастосування у зазначеній сфері, формулювання пропозиції щодо внесення змін до нормативноправових актів.

Виклад основних положень. Із набранням чинності Законом України «Про внесення змін до Господарського процесуального кодексу України, Цивільного процесуального кодексу України, Кодексу адміністративного судочинства України та інших законодавчих актів» від 3 жовтня 2017 року № 2147-VIII та Законом України «Про внесення змін до Господарського процесуального кодексу України, Цивільного процесуального кодексу України, Кодексу адміністративного судочинства України щодо вдосконалення порядку розгляду судових справ» від 15 січня 2020 року № 460-IX до чинного процесуального законодавства, в тому числі у сфері касаційного перегляду судових рішень, внесено суттєві нововведення, зокрема i визначено коло нових цивільно-процесуальних оціночних понять, серед яких: «фундаментальне значення для формування єдиної правозастосовчої практики», «значний суспільний інтерес», «виключна правова проблема», «виняткове значення для учасника справи», «висновок щодо застосування норми права у подібних правовідносинах».

Формулювання процесуального законодавства, в частині застосування оціночних понять, виступало предметом неодноразових теоретико-правових дискусій. Зокрема, Д.Д. Луспеник обгрунтовує необхідність виключення оціночних понять із норм ЦПК України, які регламентують прийнятність касаційної скарги та ухвалення нових «касаційних фільтрів» із урахуванням практики Європейського суду з прав людини [4]. У тому числі і автором даної статті зазначалось, що відсутність дефініцій оціночних понять у чинній редакції норм ЦПК України, які регламентують процедуру касаційного оскарження, є таким, що суперечить принципу правової визначеності
[5]. Натомість I. Турчин, досліджуючи оціночні поняття в судочинстві, визначає ї функціонування об'єктивною необхідністю, що трансформує казуістичні правові норми в універсальні правила [11].

I. Зеленко обгрунтовує необхідіність застосування оціночних правових понять через їх функціональне призначення, що забезпечує виконання завдань правозастосування, законодавчої економіі, формування правової культури, виступає чинником еволюції правової системи, відображає динамічний характер права та виконує прогностичну роль [2].

Загалом, погоджуючись із необхідністю застосування оціночних понять у сфері регулювання законодавцем стадії касаційного перегляду судових рішень у цивільному процесі з огляду на наявність їх функціонального призначення та сучасний ціннісний підхід до праворозуміння, слушним вважаємо пропозицію науковців щодо доцільності визначення змісту, форми та обсягу цивільно-процесуальних оціночних понять.

I.B. Турчин-Кукаріна вказує, що обсяг оціночного поняття конкретизується в процесі його тлумачення i застосування, його специфікою $€$ незамкнутий характер. Це пояснюється тим, що конкретним оціночним поняттям маркується невизначна законодавцем наперед кількість предметів, подій, станів чи явищ, а обсяг оціночного поняття складається із сукупності тих правових явищ, які наділені тими ознаками, що випливають 3 його змісту [12].

Саме труднощі, пов'язані 3 різним визначенням обсягу оціночних цивільно-процесуальних правових понять відмінними суб'єктами правовідносин, учасниками цивільного процесу та судом, як органом юрисдикції, лежать в основі проблем використання логічних прийомів правозастосування на стадії касаційного перегляду судових рішень. Зокрема, суддя Верховного Суду, к.ю.н. Луспеник Д.Д., 
зазначає, що численні оціночні терміни ЦПК України, які регулюють касаційне провадження, обумовлюють необмежений розсуд (угляд) суду ще на стадії допуску касаційної скарги, що негативно впливає на формування правосвідомості учасників цивільного процесу - споживачів суддівських послуг [4]. Суддя Верховного суду Я. Берназюк, звертаючи увагу на прогалини процесуального законодавства у сфері касаційного перегляду судових рішень щодо визначення оціночних понять, стверджує, що відсутність унормованих визначень оціночних понять та будь-яких критеріїв їх визначення вимагає саме від Великої Палати Верховного Суду та касаційних судів забезпечення вироблення єдиної судової практики шляхом надання відповідного тлумачення (правозастосування), а також встановлює напрям для формування доктринальних розробок із зазначених питань науковою правовою спільнотою [1].

Зазначені позиції практиків правозастосування процесуальних оціночних правових понять підтверджують наявність проблем щодо використання логічних прийомів, пов'язаних із визначенням обсягу конкретних оціночних термінів, вжитих у законодавстві, яке регулює процедуру касаційного перегляду судових рішень.

3 огляду на наведені обставини вважаємо доцільним доповнити положення чинного ЦПК України унормованими дефініціями цивільно-процесуальних оціночних понять на стадії касаційного провадження та сформувати нормативні критерії визначення змісту та обсягу даних оціночних термінів.

В.Г. Перепелюк, формуючи науковий висновок про застосування ч. 3 ст. 389 ЦПК України (щодо питання права, яке має фундаментальне значення), зазначає, що на роль доктринального визначення поняття «питання права, яке має фундаментальне значення для формування єди- ної правозастосовчої практики» може претендувати дефініція вітчизняних науковців: питання права, яке має фундаментальне значення для формування єдиної правозастосовчої практики, є питання про те, яким є зміст принципу права, необхідний для формулювання судом нового положення, призначеного подолати прогалину у нормативному регулюванні шляхом застосування аналогії права чи колізію між нормами права [8]. Судова практика до ознак виключної правової проблеми та питань права, які мають фундаментальне значення для формування єдиної практики, відносить: відсутність сталої судової практики, необхідність застосування аналогії закону чи аналогії права, невизначеність нормативного акта, невизначену кількість спорів із зазначеної проблеми (Ухвала Верховного Суду від 4 червня 2018 року у справі № 638/11484/17 [14]; Ухвалу Верховного Суду від 30 жовтня 2018 року у справі № 757/172/16-ц [13]). Велика Палата Верховного Суду до ознак виключної правової проблеми відносить: питання щодо дотримання принципу пропорційності; забезпечення належного балансу між приватними та публічними інтересами, справедливості судового розгляду, принципу верховенства права; відсутність усталеної судової практики у застосуванні однієї і тієї ж норми права, в тому числі наявність правових висновків суду касаційної інстанції, які прямо суперечать один одному; встановлення глибоких та довгострокових розходжень у судовій практиці у подібних справах; наявність різних наукових підходів до вирішення конкретних правових питань у схожих правовідносинах (Ухвала ВП ВС від 16.06.20 по справі № $487 / 2376 / 18$ [15]).

Ураховуючи викладені обставини, доцільно доповнити ч. 3 ст. 389 ЦПК України, що встановлює підстави для касаційного оскарження, положеннями, якими визначити поняття 
«питання права, яке має фундаментальне значення для формування єдиної правозастосовчої практики», як питання про застосування правових норм та принципів, аналогії закону та аналогіі права, що необхідні для формулювання судом єдиної практики, яка призначена подолати прогалину у нормативному регулюванні чи колізію між нормами права. Крім того, пропонуємо положення частини 5 ст. 403 ЦПК України, яка визначає поняття «виключна правова проблема» доповнити нормами, що встановлюють ознаки такої правової проблеми, зокрема: наявність неоднакової судової практики застосування тих самих норм законодавства при вирішення спорів у подібних правовідносинах; наявність невизначеної кількості спорів із зазначеної проблеми; необхідність забезпечити дотримання основоположних та фундаментальних принципів права в ході судового розгляду; наявність різних наукових підходів до вирішення конкретних правових питань у схожих правовідносинах.

Не менш актуальним є визначення змісту та обсягу процесуальних оціночних понять, вжитих законодавцем у ч. 3 ст. 389 ЦПК України: «значний суспільний інтерес», «виняткове значення для учасника справи».

Н. Надольний визначає суспільний інтерес як інтерес суспільства або усередненого представника цього суспільства, пов'язаного із забезпеченням його добробуту, стабільності, безпеки та сталого розвитку [7].

Професор А. Монаєнко суспільний інтерес передбачає у таких випадках: вирішення спорів, у яких учасниками виступає за однією категорією справ велике коло суб'єктів приватного права, або коли відбувається масове та / або значне порушення суб'єктами владних повноважень основних прав, свобод та інтересів людини й громадянина; необхідінсть допуску справ тотожної категоріі; недотримання справедливого балансу між інтере- сами заявників та інтересами суспільства [6].

Для характеристики поняття виняткового значення для учасника справи проф. А. Монаєнко, з посиланням на практику Європейського суду з прав людини, зазначає, що у справі має відбуватися порушення питань факту i права, визначення яких вимагає розгляду справи по суті щодо неспроможності держави дотриматися своїх позитивних зобов'язань в частині регулювання певного виду діяльності, яка має негативні наслідки для заявника, а також досягає такого серйозного рівня, що призводить до суттєвого перешкоджання здатності заявника користуватися своїми правами, існувала давно, була добре відома органам влади, має триваючий характер та не усунута судом першої та апеляційної інстанції [6].

Ураховуючи наведені доктринальні положення, пропонуємо доповнити ч. 3 ст. 389 ЦПК України такими ознаками понять «значний суспільний інтерес» та «виняткове значення для учасника справи»: забезпечення добробуту, стабільності, безпеки, сталого розвитку регіону та держави; розгляд значної кількості спорів із тотожними предметом та обставинами; порушення основоположних прав та свобод людини, що гарантовані Європейською конвенцією про захист прав людини та основоположних свобод, яке не усунуто в ході розгляду справи у суді першої та апеляційної інстанції.

Необхідним є також визначення поняття «висновок щодо застосування норми права у подібних правовідносинах» у ч. 2 ст. 389 ЦПК України. Суддя Верховного суду, к.ю.н. Ханова Р.Ф. зазначає, що під час розгляду та вирішення справ судді мають застосовувати механізм подолання розбіжностей у судових рішеннях, оцінювати обгрунтованість застосування в судовій практиці критерію подібності при відступі від усталеної судової практики Верховного Суду, 
керуючись принципом юридичної визначеності, який вимагає, щоб при остаточному вирішенні справи судами їні рішення гарантували розумну передбачуваність, не викликали сумнівів і забезпечували однозначність і передбачуваність правозастосування, а отже, системність і послідовність у діяльності судів [16]. У Постановах Великої Палати Верховного Суду, зокрема від 27 березня 2018 року у справі № 910/17999/16 [10] та від 11 квітня 2018 року у справі № 910/12294/16 [9], міститься підхід, згідно з яким подібність правовідносин означає, зокрема, тотожність об'єкта та предмета правового регулювання, а також умов застосування правових норм (часу, місця, підстав виникнення, припинення та зміни відповідних правовідносин). Тим самим судова практика вживає заходів щодо відображення напрямів застосування терміна «висновок щодо застосування норми права у подібних правовідносинах». Разом із тим аналіз ЦПК України вказує на відсутність обов'язку суду касаційної інстанції зазначати такий висновок у мотивувальній частині Постанови, що виноситься колегією Верховного Суду. Слушно зауважує із зазначеного приводу Д.Д. Луспеник, що законодавець зобов'язав зазначати висновок щодо застосування норми права лише палату, об'єднану палату та Велику Палату Верховного суду (ч. 2 ст. 416 ЦПК України), хоча $99 \%$ судових рішень ухвалюється колегіями суддів касаційного суду та їх практика застосовуються судами першої та апеляційної інстанції [4]. Більше того, згідно зі ст. 13 Закону України «Про судоустрій і статус суддів» висновки щодо застосування норм права, викладені у постановах Верховного Суду, є обов'язковими для всіх суб'єктів владних повноважень, які використовують у своїй діяльності нормативно-правовий акт, що містить відповідну норму права. Висновки щодо застосування норм права, викладені у постановах Вер- ховного Суду, враховуються іншими судами при застосуванні таких норм права.

Із метою усунення невизначеності вказаного оціночного поняття вважаємо за необхідне внести зміни до ст. 416 ЦПК України, якими визначити, що в мотивувальній частині постанови Верховного Суду зазначається висновок 3 питань права (правоконкретизуюче положення) у випадку, якщо касаційне провадження відкрито із підстав відсутності висновку Верховного суду у подібних правовідносинах чи питання права, яке має фундаментальне значення для формування єдиної правозастосовчої практики.

Оцінюючи в цілому нововведені цивільно-процесуальні оціночні поняття на стадії касаційного перегляду судових рішень, вважаємо оновлення законодавства в частині цивільного судочинства необхідною умовою розвитку правової системи України, проте наголошуємо на необхідності оптимізації окремих правових норм, якими визначається зміст та обсяг оціночних правових термінів.

За результати проведеного дослідження формуємо висновки:

1. Цивільно-процесуальними оціночними поняттями на стадії касаційного перегляду справи, що запровадженні ЦПК України в редакції Закону України № 460-IX від 15 січня 2020 року, $€$ : «фундаментальне значення для формування єдиної правозастосовчої практики», «значний суспільний інтерес», «виключна правова проблема», «виняткове значення для учасника справи», «висновок щодо застосування норми права у подібних правовідносинах».

2. Основою проблем щодо використання логічних прийомів правозастосування на стадіï касаційного перегляду судових рішень $€$ труднощі, пов'язані з різним визначенням обсягу та змісту оціночних цивільно-процесуальних правових понять відмінними суб'єктами правовідносин, 
учасниками цивільного процесу та судом, як органом юрисдикції (відсутність єдиного підходу до праворозуміння змісту та обсягу оціночних термінів).

3. Із метою оптимізаціі механізму правового регулювання процедури перегляду судових рішень у цивільному процесі касаційною інстанцією пропонуємо доповнити положення чинного законодавства правовими нормами, якими конкретизувати ознаки цивільно-процесуальних оціночних понять:

- доповнити ч. 3 ст. 389 ЦПК України, що встановлює підстави для касаційного оскарження, положеннями, якими визначити поняття «питання права, яке має фундаментальне значення для формування єдиної правозастосовчої практики», як питання про застосування правових норм та принципів, аналогії закону та аналогії права, що необхідні для формулювання судами єдиної практики для подолання прогалин у нормативному регулюванні чи колізій між нормами права;

- доповнити ч. 5 ст. 403 ЦПК України, яка визначає поняття «виключна правова проблема», нормами, що встановлюють ознаки такої правової проблеми, зокрема: наявність неоднакової судової практики застосування тих самих норм законодавства під час вирішення спорів у подібних правовідносинах; наявність невизначеної кількості спорів із зазначеної проблеми; недотримання основоположних та фундаментальних правових принципів в ході судового розгляду; наявність різних наукових підходів до вирішення конкретних правових питань у схожих правовідносинах;

- доповнити ч. 3 ст. 389 ЦПК України ознаками понять «значний суспільний інтерес» та «виняткове значення для учасника справи»: забезпечення добробуту, стабільності, безпеки, сталого розвитку регіону чи держави; розгляд значної кількості спорів із тотожними предметом та обставинами; порушення основоположних прав та свобод людини, що гарантовані Європейською конвенцією про захист прав людини та основоположних свобод, яке не усунуто в ході розгляду справи в суді першої та апеляційної інстанціі;

- внести зміни до ст. 416 ЦПК України, якими визначити, що у мотивувальній частині Постанови Верховного Суду зазначається висновок 3 питань права (правоконкретизуючий висновок) у випадку, якщо касаційне провадження відкрито із підстав відсутності висновку Верховного суду у подібних правовідносинах чи для вирішення питання права, яке має фундаментальне значення для формування єдиної правозастосовчої практики.

у роботі висвітлено актуальні питання та досліджено проблеми правозастосування цивільно-процесуальних оціночних понять на стадї касаційного перегляду судових рішень у цивільному проиесі України. Проаналізовано необхідність застосування цивільно-процесуальних оціночних понять у сфері регламентування правовінносин на стадї касаційного перегляду рішень у ичивільних справах. Здійснено правову характеристику циивільно-процесуальних оціночних понять, визначено їх ознаки та критерії. Вказано на прогалини правового регулювання правовідносин у зазначеній сфері, серед яких: відсутність нормативного визначення поняття «правовий висновок Верховного Суду»; відсутність нормативного визначення оціночних понять: «фундаментальне значення для формування єдиної правозастосовчої практики», «значний суспільний інтерес», «виняткове значення для учасника справи». Запропоновано дефініціі процесуальних оциночних термінів «фундаментальне значення для формування єдиної правозастосовчої практики», «значний суспільний 
інтерес», «виключна правова проблема», «виняткове значення для учасника справи», «висновок щодо застосування норми права у подібних правовідносинах». Сформовано висновки та пропозиції, спрямовані на вдосконалення ичвільно-процесуального законодавства щцодо перегляду судових рішень у касаиійному порядку, зокрема, з метою оптимізаціі механізму правового регулювання процедури перегляду судових рішень у иивільному процесі касаційною інстанцією, запропоновано доповнити положення чинного законодавства правовими нормами, якими конкретизувати ознаки циивільно-процесуальних оціночних понять: доповнити ч. $3 \mathrm{~cm} .389$ ЦПК України, що визначає підстави для касаційного оскарження, положеннями, якими визначити поняття «питання права, яке має фундаментальне значення для формування єдиної правозастосовчої практики», як питання про застосування правових норм та принципів, аналогіï закону та аналогії права, що необхідні для формулювання судом єдиної практики для подолання прогалин у нормативному регулюванні чи колізій між нормами права; доповнити ч. $5 \mathrm{~cm} .403$ ЦПК України, яка визначає поняття "виключна правова проблема», нормами, що встановлюють ознаки такої правової проблеми, зокрема: наявність неоднакової судової практики застосування тих самих норм законодавства при вирішення спорів у подібних правовідносинах; наявність невизначеної кількості спорів із зазначеної проблеми; недотримання основоположних та фундаментальних приниипів права в ході судового розгляду; наявність різних наукових підходів до вирішення конкретних правових питань у схожих правовідносинах.

Ключові слова: касаційне оскарження, касаційний фільтр, цивільний процес, оціночне поняття, Верховний Суд, касаційна скарга.
Mayka M. Problems of law enforcement of civil procedural evaluation concepts at the stage of cassation review of judicial decisions

The paper highlights current issues and examines the problems of law enforcement of civil procedural evaluation concepts at the stage of cassation review of court decisions in civil proceedings in Ukraine. The necessity of application of civilprocedural evaluation concepts in the sphere of regulation of legal relations at the stage of cassation review of decisions in civil cases is analyzed. The legal characteristic of civil-procedural evaluation concepts is carried out, their signs and criteria are defined. Gaps in the legal regulation of legal relations in this area are indicated, including: the lack of a normative definition of the concept of legal opinion of the Supreme Court; lack of normative definition of evaluation concepts: fundamental significance for the formation of a unified law enforcement practice, significant public interest, exceptional significance for the party to the case. Definitions of procedural evaluation terms fundamental importance for the formation of a single law enforcement practice, significant public interest, exclusive legal problem, exceptional importance for the party, conclusion on the application of the rule of law in such legal relations are proposed. Conclusions and proposals aimed at improving the civil procedure legislation on the review of court decisions in cassation, in particular, in order to optimize the mechanism of legal regulation of the review of court decisions in civil proceedings by the cassation instance, it is proposed to supplement the provisions of current legislation procedural evaluation concepts: to supplement Part 3 of Article 389 of the CPC of Ukraine, which defines the grounds for cassation appeal, provisions to define the concept of a question of law that is fundamental to the formation of a single 
law enforcement practice as a matter of legal norms and principles, analogies of the law and analogies of the law, which are necessary for the court to formulate a common practice to overcome gaps in regulations or conflicts between the rules of law; to supplement Part 5 of Article 403 of the CPC of Ukraine, which defines the concept of exclusive legal problem, rules that establish the characteristics of such a legal problem, in particular: the existence of different judicial practice of applying the same rules of law in resolving disputes in similar legal relations; the presence of an indefinite number of disputes on this issue; non-compliance with the fundamental and fundamental principles of law during the trial; the presence of different scientific approaches to solving specific legal issues in similar legal relations.

Key words: cassation appeal, cassation filter, civil process, evaluation concept, Supreme Court, cassation appeal.

\section{Література}

1. Берназюк Я. Вирішення виключної правової проблеми як спосіб забезпечення однакового застосування норм права. URL: https://sud.ua/ru/news/ blog / 136144 (дата звернення: 20.01.2021).

2. Зеленко І.П. Оціночне поняття у праві: функціональне призначення. URL: https: / / www.cuspu.edu.ua / images / nauk_zapiski/pravo/7_2019/9-13.pdf (дата звернення: 20.01.2021).

3. Конвенція про захист прав людини та основоположних свобод: Міжнародна конвенція від 4 листопада 1950. URL: http: / / zakon.rada.gov.ua (dama звернення: 20.01.2021).

4. Луспеник Д. Касаційні фільтри у циивільних справах: проблемні питання судового правотлумачення та правозастосування. URL: https://sud.ua/ru/ пешs / blog (дата звернення: 20.01.2021).

5. Майка М.Б., Трач O.М. Перегляд судових рішень у иивільному процесі України в касаційному порядку: правовий аналіз законодавчих змін 2020 року. Науковий вісник Міжнародного гуманітарного університету. Одеса, 2020. Bun. 43. C. 116-120.
6. Монаєнко А. Деякі питання допуску для перегляду судових рішень ВC. URL: ttps://yur-gazeta. (дата звернення: 20.01.2021)

7. Надольний Н.. Інтереси людські. Філософський енциклопедичний словник. Київ : Iнститут філософії імені Григорія Сковороди НАН України : Абрис, 2002. 742 с. 1000 екз. ББК 87я2. ISBN 966-531-128-X.

8. Перепелюк В.Г. Щодо змісту поняття «питання права, яке має фундаментальне значення для формування єдності правозастосовчої практики». URL: https:// wrw.academia.edu/38714065 (дата звернення: 20.01.2021).

9. Постанова Великої Палати Верховного Суду від 11 квітня 2018 року у справі № 910/12294/16. URL: http:/\% www.reyestr.court.gov.ua (Jama звернення: 20.03.2020).

10. Постанова Великої Палати Верховного Суду від 27 березня 2018 року у справі № 910/17999/16. URL: http:// www.reyestr.court.gov.ua (даma звернення: 20.03.2020).

11. Турчин A.I. Оціночні поняття в господарському процесуальному праві. URL: http: / / dspace.wunu.edu.ua/ (dama звернення: 20.01.2021).

12. Турчин-Кукаріна I.В. Характеристика змісту, обсягу, форми та функцій цивільно-процесуальних оціночних понять права. URL: http: / / wrere.irbis-nbuv.gov.ua / (дата звернення: 20.01.2021).

13. Ухвала Верховного Суду від 30 жовтня 2018 року у справі № $757 / 172 / 16$-и. URL: http: / / www.reyestr.court.gov.ua (дата звернення: 20.03.2020).

14. Ухвала Верховного Суду від 4 червня 2018 року у справі № 638/11484/17 URL: http: / / www.reyestr.court.gov.ua (Jama звернення: 20.03.2020).

15. Ухвала ВП ВC від 16.06 .20 no cправi №487/2376/18. URL: http:// wrw.reyestr.court.gov.иа (дата звернення: 20.01.2021).

16. Ханова Р. Тлумачення та практичне застосування в судовій практиці критерію подібності при відступі від усталеної судової практики Верховного Cydy. URL: https: / / supreme.court.gov.ua/ supreme / pres-centr/zmi/991885 / (dama звернення: 20.01.2021).

17. Цивільний процесуальний кодекс України : Закон України від 18 березня 2004 року зі змінами та доповненнями. URL: http://zakon.rada.gov.ua (Jama звернення: 20.01.2021). 